\title{
Long-Term Variability of Anatomic Features of Annual Tree Rings of Larch, Pine and Spruce in the Permafrost Zone in Central Siberia
}

\author{
M. V. Fonti ${ }^{a, b} *$, V. V. Fakhrutdinova ${ }^{c}$, E. V. Kalinina ${ }^{b}$, I. I Tychkov ${ }^{b}$, M. I. Popkova ${ }^{b}$, \\ V. V. Shishov ${ }^{b}$, and A. N. Nikolaev ${ }^{d, e}$ \\ ${ }^{a}$ Sukachev Institute of Forest, Siberian Branch of the Russian Academy of Sciences, Krasnoyarsk, 660036 Russia \\ ${ }^{b}$ Siberian Federal University, Krasnoyarsk, 660041 Russia \\ ${ }^{c}$ West-Siberian Division, Sukachev Institute of Forest, Siberian Branch of the Russian Academy of Sciences, \\ Novosibirsk, 630082 Russia \\ ${ }^{d}$ North-Eastern Federal University, Yakutsk, 677027 Russia \\ ${ }^{e}$ Melnikov Permafrost Institute, Siberian Branch of the Russian Academy of Sciences, Yakutsk, 677010 Russia \\ *e-mail: mbryukhanova@mail.ru
}

Received June 1, 2017

\begin{abstract}
Tree-ring anatomical structure is the key to understanding of adaptive specifics of xylem of various species to climate change. This is especially significant in the permafrost zone due to likely permafrost degradation. We compared anatomic features of annual rings of Dahurian larch (Larix gmelinii (Rupr.) Rupr., Larix cajanderi Mayr.), Scots pine (Pinus sylvestris L.) and Siberian spruce (Picea obovata Ledeb.) growing in the permafrost zone in Central Siberia for 1960-2011. Climatic factors affecting tree radial growth and anatomic features of tracheids of coniferous species were revealed.
\end{abstract}

Keywords: tracheids, climatic factors, structural and functional changes of wood, permafrost zone

DOI: $10.1134 / \mathrm{S} 1995425519070035$

\section{INTRODUCTION}

During the last decades, the effects of global climate change have been reported worldwide (IPCC, 2013). It is expected that, in the 21st century, climate change will contribute to further ecosystem modification at the structural and functional levels (Iverson and Prasad, 2001; Tchebakova et al., 2010), with a strong impact on high-latitude ecosystems (Serreze et al., 2000; Delisle, 2007). As a result of climate warming and changes in the precipitation regime, it is expected that the permafrost area may be subject to permafrost degradation (Shur and Jorgenson, 2007; Romanovsky et al., 2008). On the one hand, this might have a positive effect on the growth of the main forest-forming species in the region since, in addition to the direct influence of positive temperatures, the soil can be an additional source of accessible moisture. On the other hand, the growth of trees in permafrost is very specific (Kujansuu et al., 2007; Nikolaev et al., 2011; Tabakova et al., 2011), and depending on the local growing conditions, the trees can be exposed to drought, flooding or lack of nutrients (Lloyd and Bunn, 2007; Ohse et al., 2012).

Conifers are characterized by a fairly high degree of plasticity and able to adapt their anatomical structure of xylem under changing conditions. This feature allows to use the anatomical parameters of annual rings for retrospective studies (Panyushkina et al., 2003; Castagneri et al., 2015; Ziaco et al., 2016). It is known that tracheids of coniferous species simultaneously perform transport and mechanical functions (Gartner, 1995; Jagels and Visscher, 2006). Against the background of complex mechanical and physiological compromises between structural development and stress resistance, trees form tracheids with an appropriate lumen area and cell wall thickness (Eilmann et al., 2009; Hacura et al., 2015; Sviderskaya et al., 2011). The dynamics of these indices, as well as the ratio of early and late wood in the ring, are of the greatest interest for modern dendroclimatic studies (Martin-Benito et al., 2013; Fonti and Babushkina, 2016; Kuzmin and Rogovtsev, 2016).

Recent studies of the anatomical parameters of annual rings of coniferous tree species in the permafrost zone of Siberia (Ben'kova, V.E. and Ben'kova, A.V., 2006; Bryukhanova et al., 2014; Simanko, 2014; Bryukhanova et al., 2015) demonstrated interesting patterns of their variability, due to adaptive rearrangements depending on regional and local growing conditions. Based on the principles of dendrochronology (cross-dating, sensitivity to external changes, constant response to climate change), the data on the anatomical characteristics of tree rings (lumen size of the tra- 
Table 1. Description of habitats and age of the studied stands

\begin{tabular}{|c|c|c|c|c|c|}
\hline Plot & Site coordinates & $\begin{array}{c}\text { Average annual } \\
\text { air temperature, }{ }^{\circ} \mathrm{C}^{*}\end{array}$ & Rainfall mm/year ${ }^{1 *}$ & Tree species & Age, years \\
\hline Y1LA & $\begin{array}{l}62^{\circ} 08^{\prime} \mathrm{N} \\
128^{\circ} 39^{\prime} \mathrm{E}\end{array}$ & -10.4 & 238 & Larix cajanderi & 199 \\
\hline SPP & $\begin{array}{l}62^{\circ} 15^{\prime} \mathrm{N} \\
129^{\circ} 37^{\prime} \mathrm{E}\end{array}$ & -10.4 & 238 & Pinus sylvestris & 218 \\
\hline TURA & $\begin{array}{l}64^{\circ} 29^{\prime} \mathrm{N} \\
100^{\circ} 35^{\prime} \mathrm{E}\end{array}$ & -9.0 & 370 & $\begin{array}{l}\text { Larix gmelinii } \\
\text { Picea obovata }\end{array}$ & $\begin{array}{l}110 \\
107\end{array}$ \\
\hline
\end{tabular}

* Based on climate data from the nearest weather stations "Tura" and "Yakutsk" from 1960 to 2011.

cheids, cell wall thickness, wood density) are a detailed and reliable source of information on intraannual changes of environmental conditions. Such knowledge provides a unique basis both for reconstruction and for predicting the variability of the conductive and mechanical parameters of xylem under climate change. In this regard, the study of the xylem anatomical parameters allows us to understand the long-term (several decades or even hundreds of years) and short-term (within one season) structural and functional changes in the xylem associated with changing growing conditions. In our study, based on an analysis of the structure of the xylem of Dahurian larch, Scots pine, and Siberian spruce from various habitats in the zone of continuous permafrost, over the last 52 years, attention was focused on long-term changes in the structural and functional anatomical parameters of wood and the influence of climatic factors on their variability.

\section{MATERIALS AND METHODS}

Studies of Dahurian larch (Larix gmelinii (Rupr.) Rupr., Larix cajanderi Mayr.), Scots pine, (Pinus sylvestris L.) and Siberian spruce (Picea obovata Ledeb.) were carried out in the zone of the continuous permafrost zone in Central Siberia (Table 1).

The first site (TURA), on which samples of Dahurian larch and Siberian spruce were collected, is located $10 \mathrm{~km}$ from Tura village of Evenki district of Krasnoyarsk Krai $\left(64^{\circ} 29^{\prime}\right.$ N $100^{\circ} 45^{\prime}$ E, 589 m above sea level). The area is located in a strong continental climate. According to the weather station Tura (from 1936 to 2012), the average annual air temperature was minus $9^{\circ} \mathrm{C}$ and precipitation was less than $400 \mathrm{~mm}$ per year. Winter lasts about 8 months a year, and temperatures can drop below minus $60^{\circ} \mathrm{C}$ from December to February. The average temperature of the coldest month of the year, January, is minus $35^{\circ} \mathrm{C}$. Summer is short, from late June to mid-August, while the average temperature of July, as the warmest month, is $17^{\circ} \mathrm{C}$. In the study area, larch stands of class $\mathrm{V}$ bonitet, green mosses group of forest types predominate (Abaimov et al., 1997). The study site was located on a plateau, dominated by larch with the above-ground vegetation dominated by Ledum palustre L., the age of the trees was about 110 years, and the height was about $9 \mathrm{~m}$ with an average stem diameter of $11.5 \mathrm{~cm}$. The soils were alluvial humus; the depth of the active soil layer in August was about $60 \mathrm{~cm}$.

The climate of the territory of Central Yakutia, where two other studied sites were located, is also very continental, the average annual air temperature is minus $9.8^{\circ} \mathrm{C}$, and the amount of precipitation is 233 $\mathrm{mm}$ per year (according to the Yakutsk weather station from 1936 to 2012). The average January temperature is minus $41^{\circ} \mathrm{C}$, in July it is $19^{\circ} \mathrm{C}$. The site (SPP) was chosen near the scientific station of the Institute for Biological Problems of Cryolithozone SB RAS "Spasskaya Pad" $\left(62^{\circ} 15^{\prime} \mathrm{N}, 129^{\circ} 37^{\prime} \mathrm{E}, 220 \mathrm{~m}\right.$ above sea level) $25 \mathrm{~km}$ north-east of Yakutsk. Pine bearberry Vacciniaceae group of forest types prevails there. Sandy loamy podzolized soil, with a normal degree of drainage, has a maximum depth of active soil layer reaching $50 \mathrm{~cm}$. Pine samples of co-dominant trees about 218 years old, $20 \mathrm{~m}$ high, stem diameter at a breast height of $26 \mathrm{~cm}$ were collected on this site.

The third site (Y1LA) with coordinates $62^{\circ} 08^{\prime} \mathrm{N}$, $128^{\circ} 39^{\prime} \mathrm{E}, 230 \mathrm{~m}$ above sea level is located at a distance of $60 \mathrm{~km}$ west of Yakutsk and represented mainly by larch stands with a developed undergrowth of blueberry-green mosses. Soil type is permafrost-taiga paleyellow loamy, with seasonal thawing depth of $50 \mathrm{~cm}$. Larix cajanderi samples were collected from dominant trees, 199 years old, $15 \mathrm{~m}$ high and $25 \mathrm{~cm}$ in diameter.

Wood samples (cores) were taken from 15-20 trees of each species on the site with $5 \mathrm{~mm}$ borer from the stems at a height of $1.3 \mathrm{~m}$ from the soil level. Annual tree ring widths of individual trees were measured according to a well-known methodology (Rinn, 1996). Statistical verification of the quality of cross-dating was carried out using the specialized COFECHA program (Holmes, 1983). Based on dendrochronological analysis, for the histometric measurements, 5-7 trees were selected on each site, characterized by the highest correlation coefficients with the master chronology $(0.60-0.80)$ and the general course of growth over all years of lifespan. Each wood sample (core) was softened by boiling in water, then thin $(20 \mu \mathrm{m})$ transverse 
sections of wood were obtained using a microtome. The sections were stained with methylene blue solution for 2-3 min. All cell characteristics of wood samples for the period from 1960 to 2011 were measured using the AxioScope image analysis system and AxioVision SE64 Rel 4.9.1 software (Carl Zeiss, Germany), which determined the sizes and areas of cell structures and gaps in different parts of annual rings in semi-automatic mode according to the image of a cross section of wood.

In each annual ring, five rows of cells with the largest cross-sectional area were selected. Radial cell sizes $(D)$, cell wall thickness $(C W T)$, and tangential cell sizes $(T)$ were measured and then the cell wall area $(C W A)$ and lumen area $(L U M)$ were calculated (Vaganov et al., $2007)$. In each ring, the sizes of the zones of early $(E W$, $2 C W T<L D)$ and late $(L W, 2 C W T>L D)$ wood were established and average values of linear and areal parameters of tracheids were calculated according to Mork's index (Denne, 1989), based on the ratio of the width of the double cell wall to the radial size of the lumen $(L D)$.

Wood density $(D E N)$ was estimated as the ratio of the cell wall area to the total cross-sectional area of the cell (Vaganov, 1996), and for simplification of the calculations, the shape of the cell was assumed to be rectangular:

$$
D E N=\frac{2 C W T(D+T-2 C W T)}{D T},
$$

where $D$-radial cell size, $C W T$-cell wall thickness, $T$-tangential cell size.

The water transport efficiency $(C O N)$ was estimated by the volumetric flow rate of the fluid in the tracheid (Sviderskaya et al., 2011). According to the Hagen-Poiseuille equation, the volumetric velocity of a laminar fluid flow is proportional to the fourth power of its radius or the second power of the crosssectional area. Thus, the water transport efficiency $C O N$ is proportional to the second power of the radial size of the lumen $C O N=L U M^{2}$. In the calculations, we did not consider the resistance of the end pores, which affect the amount of water supply (Sperry et al., 2006). The values of this parameter for early and late wood, on average for the ring, were calculated as the arithmetic mean.

An analysis of the influence of climatic factors on the variability of the tree-ring width and anatomical parameters of wood was carried out based on Pearson correlation coefficients between generalized index chronologies and monthly average climatic data (rainfall and air temperature from the nearest meteorological "Tura" and "Yakutsk" stations) for the total period from 1960 to 2011 (significant correlation at $p<0.05$ begins with a threshold of 0.273 ).

\section{RESULTS AND DISCUSSION}

An analysis of the variability of the radial growth of all tree species over the study period (1960-2011) showed both different intra-annual variability and different trends (Fig. 1a), despite the similar average values of the tree-ring width $(0.36 \pm 0.20 \mathrm{~mm}$ for larch from Evenkia and Yakutia, $0.33 \pm 0.08 \mathrm{~mm}$ for pine from Spasskaya Pad and $0.31 \pm 0.05 \mathrm{~mm}$ for spruce from Evenkia, respectively). A clearly expressed negative trend of radial growth was observed for larch and pine trees from Yakutia, while no significant changes were found for spruce from Evenkia. For larch from the same site, increased radial growth was observed, especially over the last decade. The results of comparison of radial growth $(T R W)$ of the studied species from Yakutia with the estimated wood density $(D E N)$ (Figs. 1a, 1b) showed a significant positive correlation for pine $(R=0.52, p<0.05)$, and insignificant for Larix cajanderi $(R=0.13, p>0.05)$, while the value of water transport efficiency $(C O N)$ (Fig. 1c) was in significant agreement with changes in radial growth for the two studied species in this territory $(R=0.61$ and $0.57(p<0.05)$, for pine and larch, respectively). At the same time, Larix gmelinii and Siberian spruce from Evenkia showed a steady, but insignificant, increase in the calculated parameters at which the relationship between water supply efficiency and radial growth for larch is significant $(R=0.71, p<0.05)$, but insignificant for spruce $(R=0.22, p>0.05)$. An insignificant positive correlation was obtained between $D E N$ and $T R W(R=0.22$ and $0.25, p<0.05$, for larch and spruce, respectively).

Considering the features of the tree-ring anatomical structure of different species of coniferous trees of permafrost zones of Central Siberia, it should be noted that there are differences in both the calculated values of the cell wall area of the tracheids and the lumen area, and in the absolute values of the linear parameters of the tracheids for the zone of early and late wood (Fig. 2). For example, the annual rings of spruce from Evenkia and pine from Spasskaya Pad were characterized by the smallest lumen size in comparison with larch species (mean \pm standard deviation for early and late wood: spruce $-L D_{\text {ew }}=21.8 \pm 7.4 \mu \mathrm{m}, L D_{\mathrm{lw}}=4.3 \pm 2.4 \mu \mathrm{m}$, pine $-L D_{\text {ew }}=28.3 \pm 10.5 \mu \mathrm{m}, L D_{\mathrm{lw}}=6.1 \pm 1.9 \mu \mathrm{m}$, respectively). The cell wall thickness was also significantly lower for evergreen conifers compared to deciduous conifers. At the same time, it should be noted that the annual rings of the Larix gmelinii and Larix cajanderi were characterized by different sizes of tracheids (for example, the radial size of the early wood lumen of Larix gmelinii in Evenkia was almost $20 \%$ smaller than that of the larch in Yakutia $\left(L D_{\mathrm{ew}}=35.9 \pm\right.$ $10.1 \mu \mathrm{m}, L D_{\mathrm{ew}}=44.1 \pm 11.2 \mu \mathrm{m}$, respectively).

A correlation analysis of the measured and calculated parameters of the annual rings of the studied species on the average for the ring, as well as for early and late wood (Fig. 3) showed that the radial growth of 
(a)

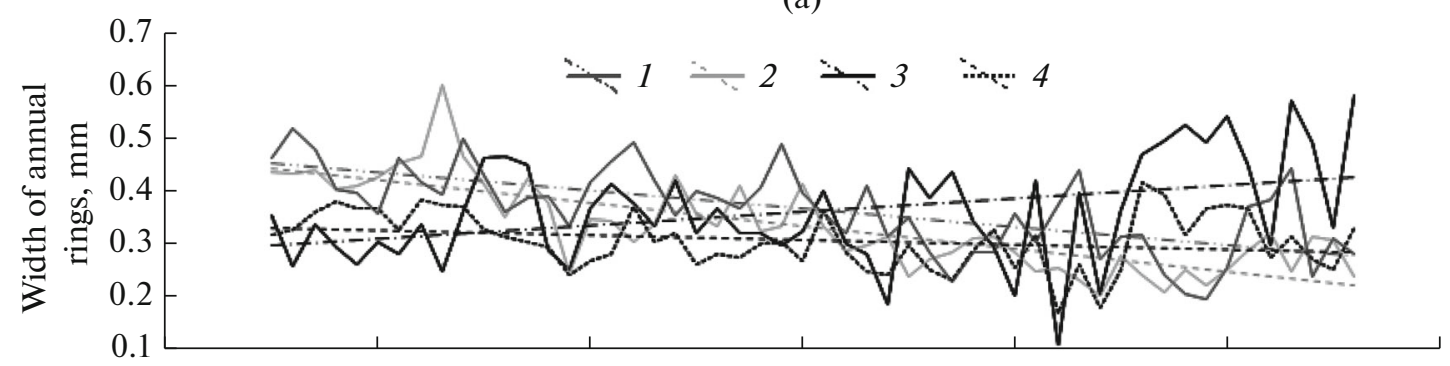

(b)

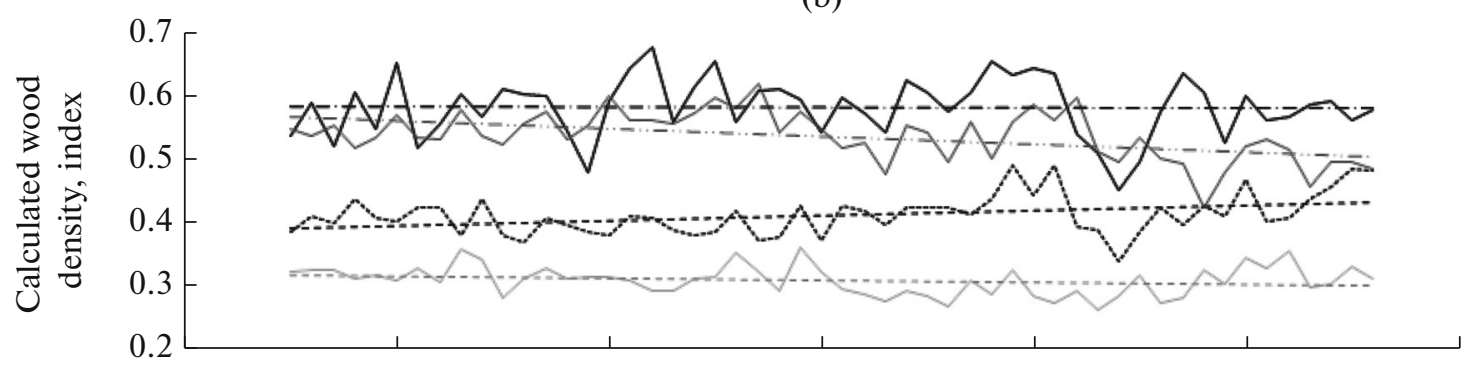

(c)

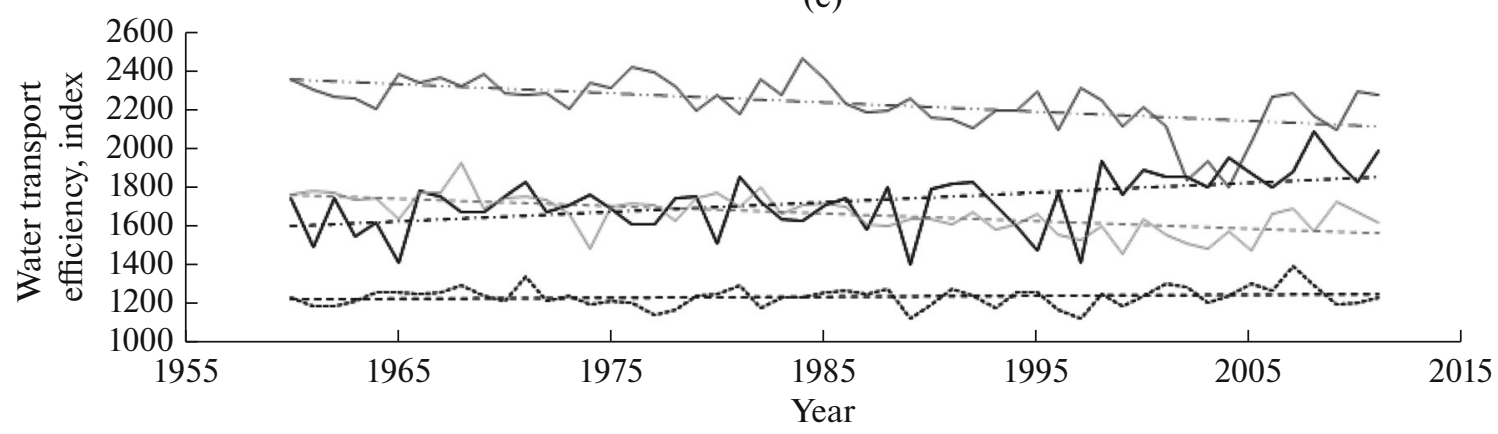

Fig. 1. Annual rings width (a), calculated wood density (b) and water transport efficiency (c) of the studied species. (1) Larix cajanderi, Yakutsk; (2) Pinus sylvestris, Spasskaya Pad; (3) Larix gmelinii, Tura; (4) Picea obovata, Tura. Dotted lines indicate linear trends.

spruce was least associated with changes in the size of the anatomical parameters of tracheids ( 9 out of 21 parameters). The lack of correlation firstly indicates various species-specific features of growth variability and suggests that, i.e., under favorable conditions, a higher number of tracheids are formed that affect the growth rate, while their linear and areal sizes changed insignificantly. Secondly, it opens up the possibility of extracting different than $T R W$ climate signal in other parameters of the annual ring. For Larix gmelinii from Evenkia, as well as for Larix cajanderi from Yakutia, the relationship between the anatomical parameters and tree-ring width was more significant (14 parameters from 21), and for pine from Spasskaya Pad, the highest correlation of tracheid sizes with radial growth (18 parameters from 21 ) was detected. Thus, under favorable conditions, changes in the width of the annual rings occur together with an increase in the size of the tracheids, their lumen, and the thickness of the cell wall.
Our correlation analysis of the area sizes of tracheids ( $C W A$ and $L U M$ ) for the studied species of one territory showed high positive relation, which indicates similar structural and functional changes due to climatic factors and local growing conditions. Thus, i.e., the cell wall area of spruce and larch from Evenkia showed a positive relationship $R=0.47$ for $p<0.05$, and the same correlation was observed for the lumen area of the tracheids $(R=0.43, p<0.05)$. For trees from Yakutia, these correlations were 0.49 for $C W A$ and 0.19 for $L U M(p<0.05)$, respectively. It should be noted that there was no significant correlation of the anatomical parameters of tracheids in trees of various habitats.

In order to identify long-term trends in the variability of climatic parameters (air temperature and rainfall) for the growing climatic season (May-August) for the period 1960-2011, the data for the two study areas (Evenkia and Yakutia) were compared. The comparison showed both similar characteristics and significant 
(a)

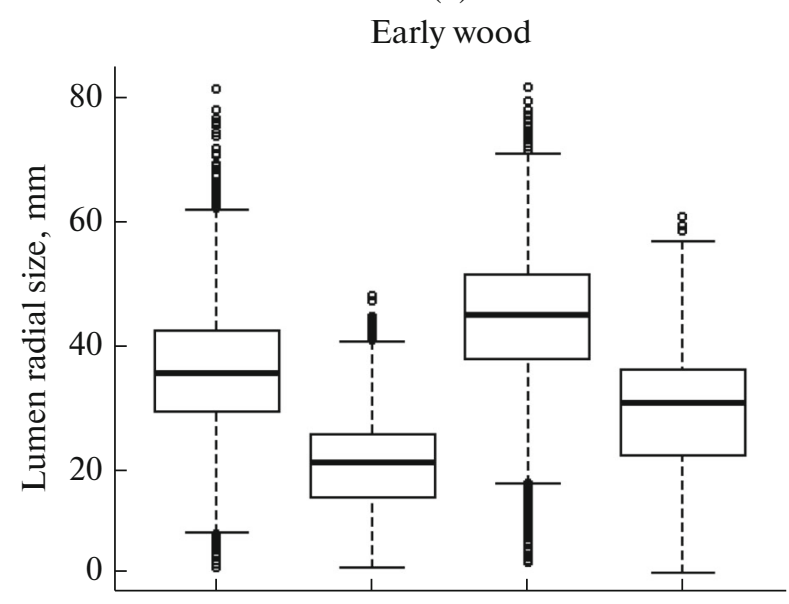

(c)

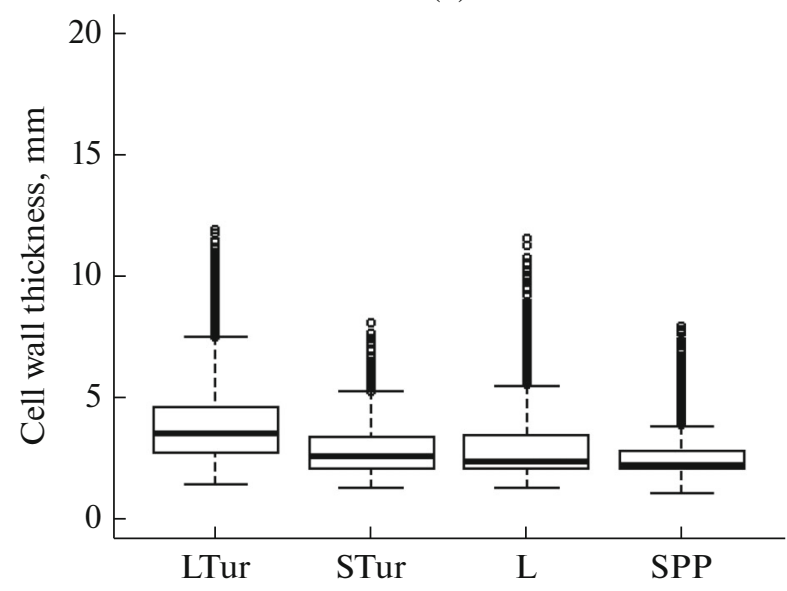

(b)

Late wood

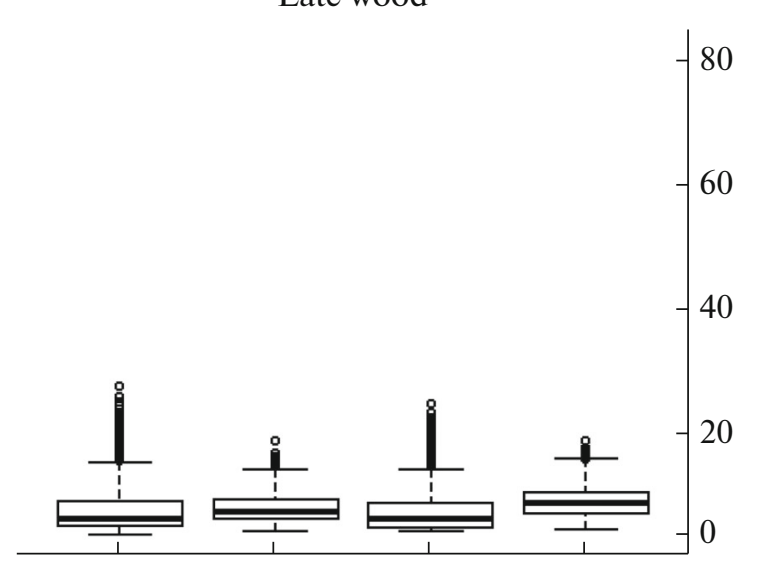

(d)

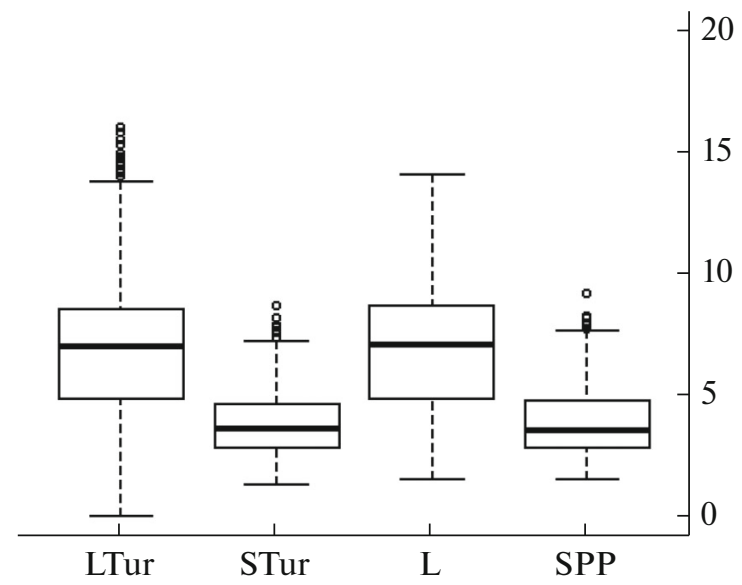

Fig. 2. Box plot for radial lumen size $(a, b)$ and cell wall thickness of tracheids $(c, d)$ in the zone of early and late wood in the annual rings of the studied species. LTur-Larix gmelinii, Tura; L_Larix cajanderi, Yakutsk; STur-Picea obovata, Tura; SPPPinus sylvestris, Spasskaya Pad. The line inside the box shows the median, the size of the box is determined by the lower and upper quartiles ( 25 and $75 \%$ of the sample, respectively), error bars - the minimum and maximum value, points outside-outliers.

differences in the variability of monthly average data. The geographical location of the study areas and the change in climatic conditions from West to East Siberia caused differences in average air temperature and rainfall from May to August $\left(11.34^{\circ} \mathrm{C}\right.$ and $200.86 \mathrm{~mm}$, $14.35^{\circ} \mathrm{C}$ and $128.85 \mathrm{~mm}$, for Tura and Yakutsk, respectively). A significant increase in May temperatures was observed for the two studied regions, as well as an increase in temperature in June. However, an increase in July air temperature for Yakutsk, which was not observed for Tura, should be noted. The amount of precipitation in May, July and August remained relatively stable for Yakutsk, with a slight increase in June. For the Tura, positive trends for precipitation in May and August and negative in June-July should be noted. The correlation between climatic data for different months was not detected.

The results of the dendroclimatic analysis, the influence of air temperature and rainfall on the tree radial growth and size of the larch and spruce tracheids from Evenkia for the period 1960-2011 showed that the June temperature had a positive effect on the treering width of the studied species (Table 2). The radial growth was positively affected by temperature in July $(R=0.34, p<0.05)$. The significance of the conditions of these two months for the growth of trees completely coincides with the previously obtained results (Ben'kova, V.E. and Ben'kova, A.V., 2006). According to these results, the influence of temperature in the northern territories as the main factor limiting growth did not depend on the species status of trees and habitats, and the contribution of other climatic factors was due to local conditions. Despite the absence of a significant correlation between the radial growth of larch and spruce and May temperatures for the total period, its increase over the past ten years stimulated the beginning of the growth season at an earlier date and thus had a positive effect on the tree-ring width $(R=$ 
(a)

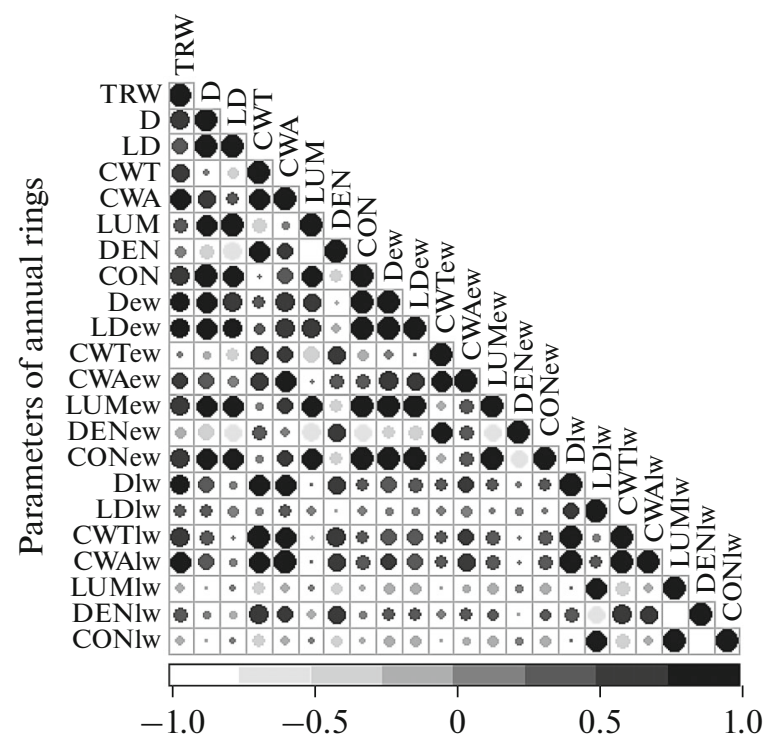

(c)

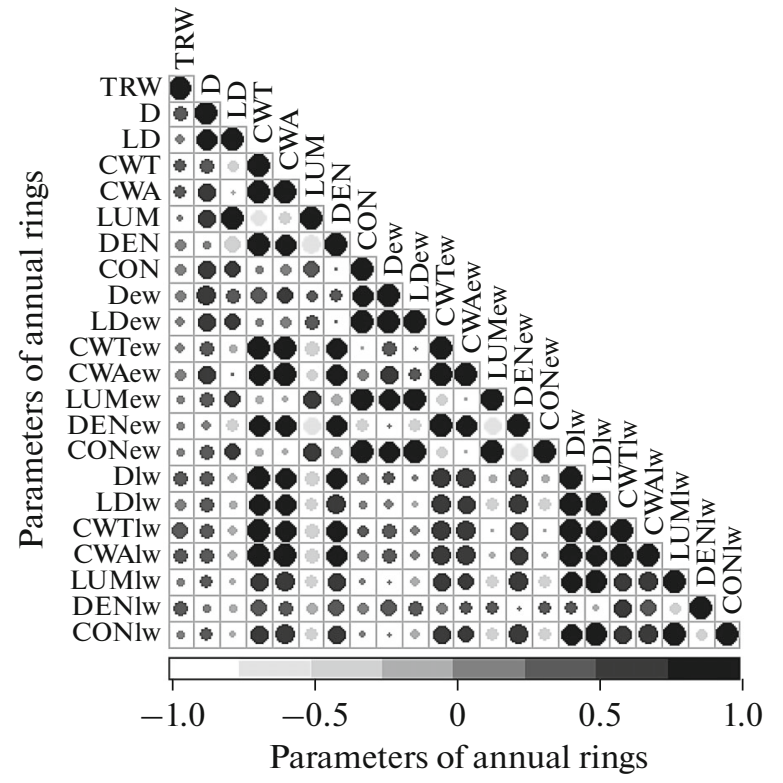

(b)

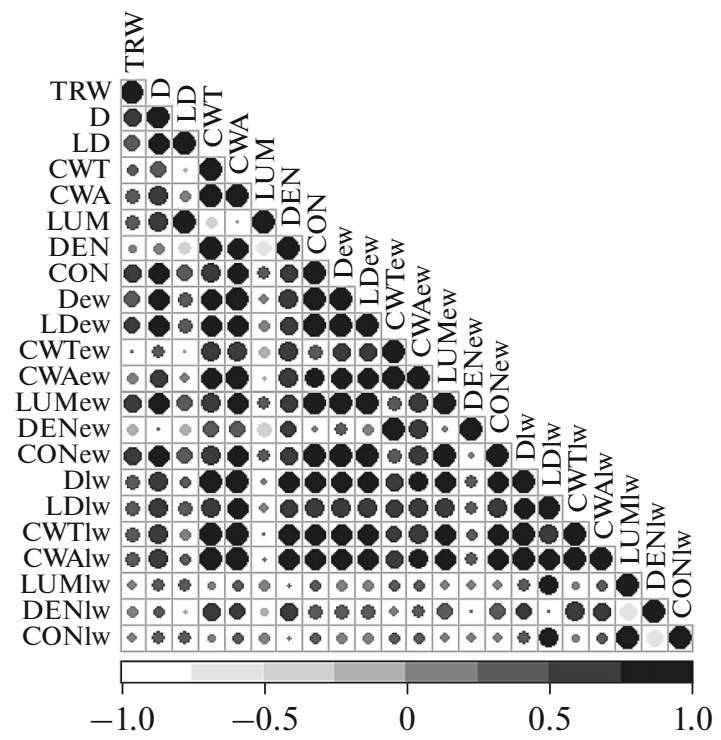

(d)

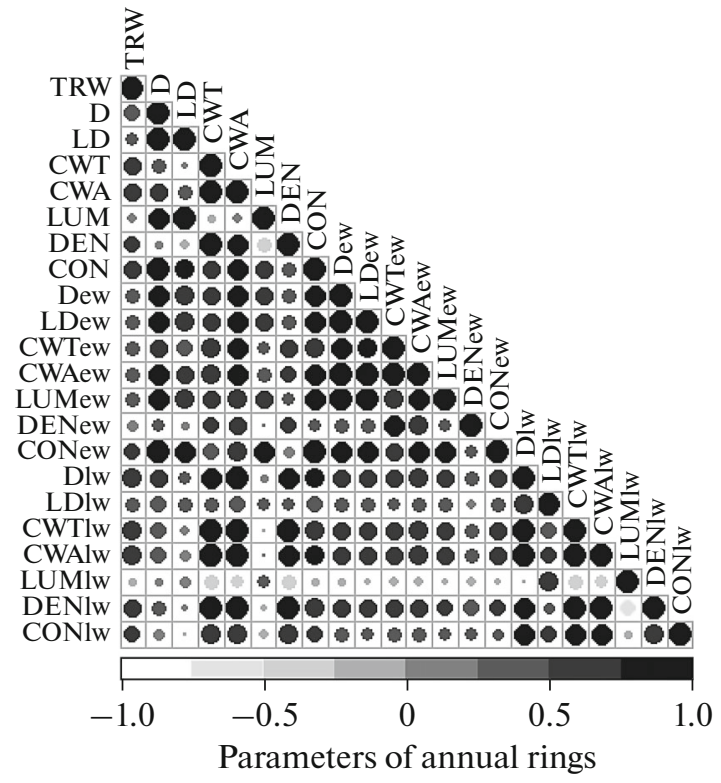

Fig. 3. Correlation coefficients of radial growth $(T R W)$ and anatomical parameters of wood ( $D$-radial cell size, $L D$-radial lumen size, $C W T$-cell wall thickness, $C W A$-cell wall area, $L U M$-lumen area, $D E N$-the calculated density of wood, $C O N-$ calculated water transport efficiency) on average for the ring and for early $(e w)$ and late $(l w)$ wood of the studied species for the general period 1960-2011; (a) Larix gmelinii, Tura; (b) Larix cajanderi, Yakutsk; (c) Picea obovata, Tura; (d) Pinus sylvestris, Spasskaya Pad). The scale at the bottom of the graphs shows correlation coefficients from -1 to 1 , significant correlation at $p<0.05$ begins with a threshold of 0.273 .

$0.37-0.43, p<0.05)$. Significant correlation between precipitation and radial growth was not found. It should be noted here that the monthly climatic data were used in the calculations, in which the influence of short-period weather changes may not be fully taken into account. For example, when applying the simulation model of the tree ring formation of Vaganov-Shashkin rings (Shashkin and Vaganov, 1993; Vaganov et al., 2006) to the studied species in
Evenkia (Shishov et al., 2016) using daily climate data, the authors found limitation of the growth of larch by soil moisture during two-three weeks in the middle of the growing season. This effect can be caused by insufficient available moisture in the soil due to high air temperatures and increased transpiration with a limited amount of precipitation and a relatively shallow root-inhabited layer, which did not allow the use of resources during permafrost thawing. For spruce, such 
Table 2. Significant correlation coefficients $(p<0.05)$ of tree-ring width $(T R W)$, cell wall area $(C W A)$, the calculated wood density $(D E N)$ and water transport efficiency $(C O N)$ of studied species with climatic parameters* during 1960 to 2011

\begin{tabular}{|c|c|c|c|c|c|c|c|c|c|c|c|c|c|}
\hline \multirow{2}{*}{ Zone } & \multirow{2}{*}{ Parameter } & \multicolumn{12}{|c|}{ Month } \\
\hline & & IX -1 & $\mathrm{X}-1$ & $\mathrm{XI}-1$ & XII-1 & I & II & III & IV & $\mathrm{V}$ & VI & VII & VIII \\
\hline & \multicolumn{13}{|c|}{ Larix gmelinii Rupr. (Rupr.), Tura } \\
\hline \multirow{4}{*}{$\varliminf_{\gtrsim}^{\bigotimes}$} & $T R W$ & & & & -0.41 & & & & & \multirow[b]{4}{*}{0.28} & \multirow{3}{*}{$\begin{array}{r}\mathbf{0 . 6 0} \\
\mathbf{0 . 5 5} / \\
-0.31\end{array}$} & & \\
\hline & $C W A$ & & & & -0.29 & & & & & & & & \\
\hline & $D E N$ & & & & & & & & & & & & \\
\hline & $C O N$ & & & & & & & & & & 0.50 & & \\
\hline \multirow{3}{*}{ 过 } & $C W A$ & & & & \multirow[t]{3}{*}{-0.32} & & & & & \multirow{3}{*}{-0.30} & 0.27 & & \\
\hline & $D E N$ & & & & & & & & & & -0.31 & & \\
\hline & $C O N$ & & & & & & & & & & 0.54 & & \\
\hline \multirow{3}{*}{$\exists$} & & & & & \multirow{3}{*}{-0.30} & & & & & & $0.57 /$ & & \\
\hline & $D E N$ & & & & & & & & & & 0.45 & 0.48 & 0.34 \\
\hline & $C O N$ & & & & & & & & & & -0.31 & -0.52 & -0.44 \\
\hline & & & & & Pic & a obova & $a$ Ledeb & ., Tura & & & & & \\
\hline & $T R W$ & & & & & -0.28 & & & -0.33 & & 0.56 & 0.34 & \\
\hline 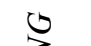 & $C W A$ & & 0.32 & & -0.33 & & & 0.31 & -0.30 & 0.29 & 0.31 & & \\
\hline 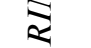 & $D E N$ & & 0.43 & & & & & 0.31 & -0.36 & & & & \\
\hline & $C O N$ & & & & -0.33 & & & & & & & & \\
\hline & & & & & $\begin{array}{l}-\mathbf{- 0 . 3 0 /} \\
-0.37\end{array}$ & & & & & 0.33 & & & \\
\hline $\overrightarrow{|c|}$ & $D E N$ & & & & & & & 0.32 & & & & & \\
\hline & $C O N$ & & & -0.30 & -0.28 & & -0.28 & & & & & & \\
\hline & $C W A$ & & 0.44 & & & & & 0.35 & -0.37 & & 0.33 & 0.35 & \\
\hline \pm & $D E N$ & & & & -0.38 & & & & & & & 033 & \\
\hline & & & & & & & & & & & & & \\
\hline & $C O N$ & & 0.31 & & & & & 0.32 & -0.39 & & & & \\
\hline & & & & & Larix & cajande & $i$ Mayr. & Yakutsl & & & & & \\
\hline & $T R W$ & & & & -0.29 & & & & & & & & \\
\hline 2 & $C W A$ & & & & & -0.37 & & -0.43 & & & $\begin{array}{r}0.36 / \\
-\mathbf{0 3 3}\end{array}$ & -0.38 & \\
\hline 2 & $D E N$ & & & & 0.35 & & & & & & 0.34 & -0.44 & -0.30 \\
\hline & $C O N$ & & & & & & & & & & 0.32 & & \\
\hline & & & & -0.30 & & -0.39 & & -0.29 & & & $\begin{array}{r}0.39 / \\
-\mathbf{0 . 4 1}\end{array}$ & -0.34 & \\
\hline E & $D E N$ & & & -0.37 & & -0.30 & & & & & -0.44 & & \\
\hline & $C O N$ & & & & & & -0.30 & -0.31 & & & 0.31 & & \\
\hline & $C W A$ & & & & & -0.33 & & -0.49 & & & 0.30 & -0.38 & \\
\hline 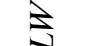 & $D E N$ & & & & & & & & & & & -0.41 & \\
\hline & $C O N$ & & & & & & & & & & -0.29 & & \\
\hline & & & & & Pinus & ylvestris & L., Spas & skaya $\mathrm{Pc}$ & & & & & \\
\hline & $T R W$ & & & & & & & & & 0.29 & & & \\
\hline ৫ & $C W A$ & & & & & & -0.31 & & & & -0.28 & -0.31 & \\
\hline$\grave{\gtrless}$ & $D E N$ & 0.37 & & & & & -0.32 & & & & & 0.28 & \\
\hline & $C O N$ & & & & & -0.31 & & & & & & & \\
\hline
\end{tabular}


Table 2. (Contd.)

\begin{tabular}{|c|c|c|c|c|c|c|c|c|c|c|c|c|c|}
\hline \multirow{2}{*}{ Zone } & \multirow{2}{*}{ Parameter } & \multicolumn{12}{|c|}{ Month } \\
\hline & & IX-1 & $X-1$ & XI-1 & XII-1 & I & II & III & IV & V & VI & VII & VIII \\
\hline $\overrightarrow{|c|}$ & $\begin{array}{l}C W A \\
D E N \\
C O N\end{array}$ & & & & & $\begin{array}{l}-0.31 \\
-0.30\end{array}$ & & & & & -0.31 & -0.29 & \\
\hline$\Delta$ & $\begin{array}{l}C W A \\
D E N \\
C O N\end{array}$ & & & & & & -0.29 & & & & & & \\
\hline
\end{tabular}

* Bold-correlation with air temperature, regular font-correlation with amount of precipitations, empty cells-insignificant at $p<0.05$ correlation. Calculation period-from September of the previous year (IX-I) to August of the current year (VIII). RING-the average values of the ring, $E W$-early wood, $L W$-late wood.

an effect was not established. This is most likely due to the fact that the spruce trees grew in wetter habitats on less drained soils and did not experience water deficit during the growing season.

Significant negative correlations of the annual rings of larch and spruce from Evenkia with the amount of winter precipitation should be noted. As was estimated earlier (Vaganov et al., 1999), the size of the snow cover affects the rate of its descent and the beginning of the growth season, which in turn affects the magnitude of the radial growth of trees. Spruce was also characterized by the negative impact of April precipitation (precipitation in the form of snow for a given territory), when an increase in snow cover on poorly drained soils can lead to even higher water content at the beginning of the growth season and further limit the growth of this species.

Due to the fact that some of the anatomical parameters of the larch tracheid are related to the magnitude of the radial growth, their response to climatic factors had a similar character. June temperatures turned out to be one of the most significant factors that had a positive effect not only on the growth of trees, but also on the majority of the tracheid parameters (Table 2). At the same time, early wood was characterized by an inverse relationship, when an increase in June temperature had a negative effect on the wood density and a positive effect on the efficiency of water transport. In other words, at high temperatures, tracheids with a larger lumen area and a less wide cell wall were formed. The division of the ring into early and late wood provided additional information on the influence of climatic factors of other months on tree growth. A significant positive correlation of the density of late wood with the temperatures in July and August and a negative correlation with the estimated efficiency of water transport of late wood should be noted.

The influence of the climatic conditions of the vegetation period on the growth of Larix cajanderi and Pinus sylvestris from Yakutia was already noted earlier (Nikolaev et al., 2011) and was partially confirmed by the results of our study (Table 2). The analysis of the relationship between the anatomical parameters of annual rings and air temperature showed that the high temperatures of the summer months (June-July) had a negative effect on the cell wall area of the tracheids of both pine from Spasskaya Pad and larch from Yakutsk. Increase of temperatures in July-August also negatively affected the wood density of larch. Such results differ from the well-known ones (Briffa et al., 2001; Davi et al., 2003), when an increase in air temperature in the northern latitudes contributed to the formation of denser wood. Under the conditions considered in this study, an increase in summer temperatures with a minimum amount of precipitation or even their absence caused a water deficiency and inhibited the photosynthesis processes and the formation of assimilates (Bréda et al., 2006), which subsequently can be used for the formation of cell walls of the tracheid. In this regard, the amount of precipitations in June allowed not only the formation of tracheids with a large lumen for more efficient water transport, but also affected the cell wall area and the wood density of larch.

In order to establish how tree-ring parameters of the studied species changed in response to changing environmental conditions for the period 1960-2011, the "sliding response functions" method was applied (Simanko et al., 2013), but for a long-term rather than intra-season interval. In this case, the correlation between the parameters of the annual rings for the "window" of 20 years with a shift of 1 year was calculated (for example, 1960-1979, 1961-1980, etc.). In total, from 1960 to 2011, correlations for 33 periods were obtained (significant correlation for $p<0.05$ begins with a threshold of 0.444 ). It was interesting to consider in more detail the stability of the climate signal recorded in such parameters as $T R W, C O N$ ew and $D E N$ lw. Correlations of these parameters with the June air temperature, which was mainly affected tree growth rate of coniferous species in this territory, showed the most stable signal for the latewood density of the Dahurian larch from Evenkia (Fig. 4). For the tree-ring width and the efficiency of the water supply, the signal was not always stable. A similar character 


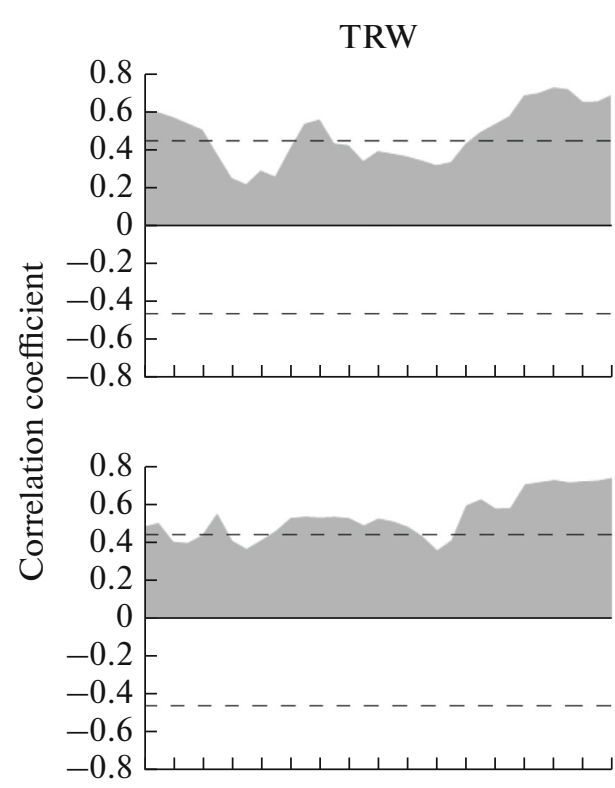

(a)
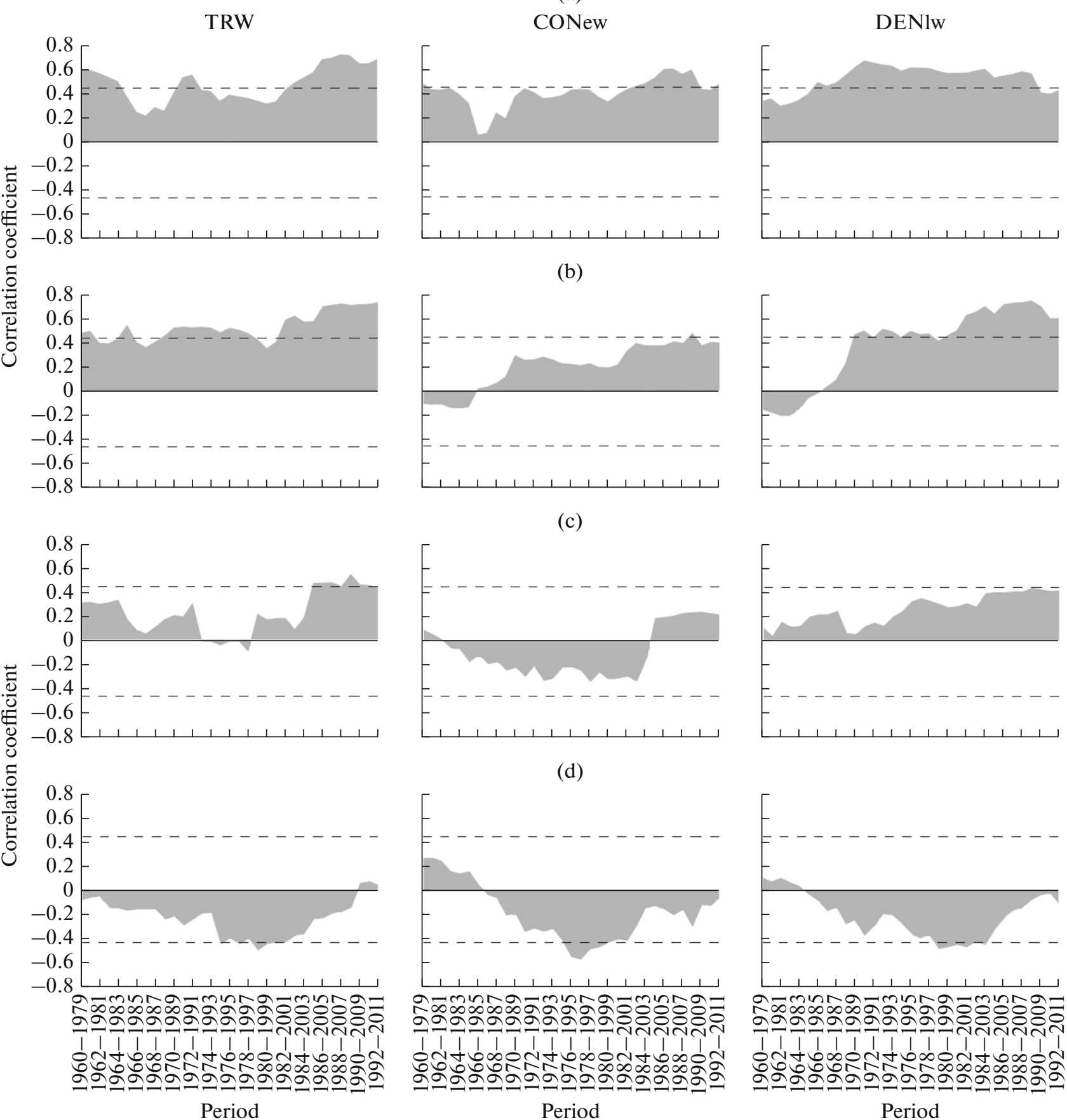

(c)

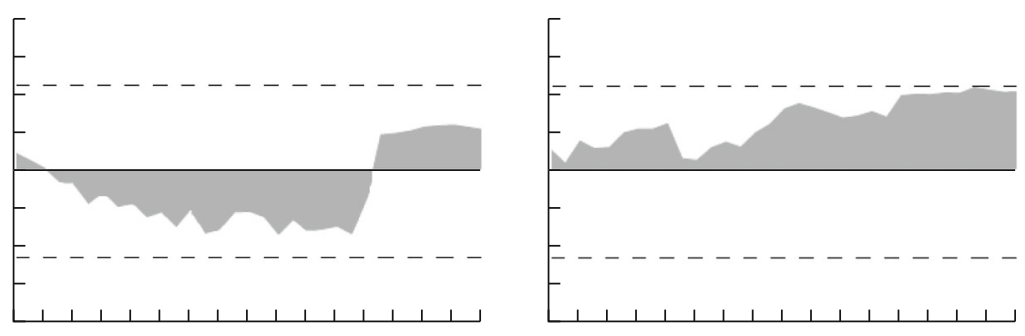

(d)
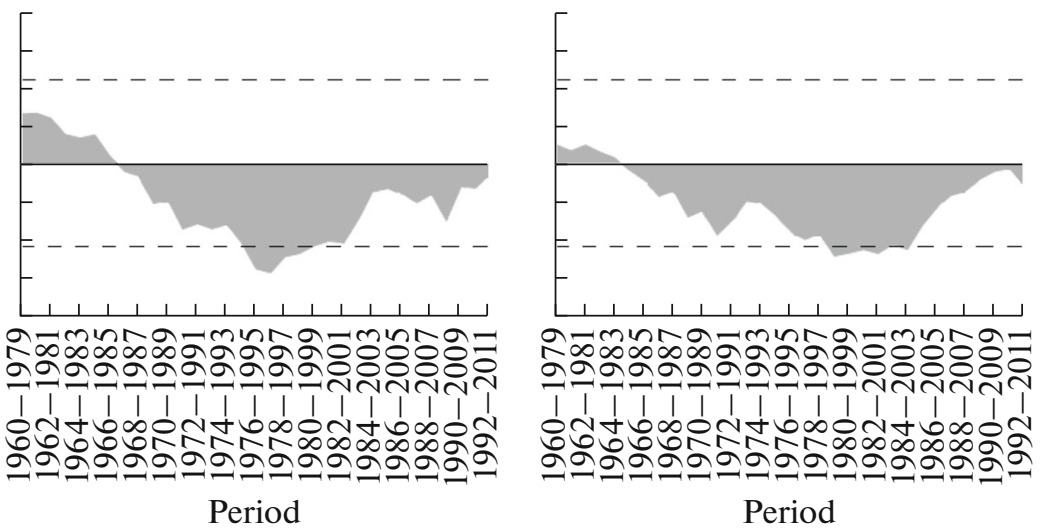

Fig. 4. Sliding correlation coefficients of tree-ring width (TRW), the calculated water transport efficiency of early wood (CONew) and late wood density (DENlw) with June air temperature for the period 1960-2011 (window = 20 years, step $=1$ year). (a) Larix gmelinii, Tura; (b) Picea obovata, Tura; (c) Larix cajanderi, Yakutsk; (d) Pinus sylvestris, Spasskaya Pad. The dashed line indicates the critical values of the coefficients at $p<0.05$.

was observed for the correlation of the parameters of spruce from Evenkia with the temperature of June. It is interesting to note the change of the influence of this factor on the density of spruce during the entire study latewood period from negative to stable positive. For the larch from Yakutia, the temperature signal in the studied parameters was considered to be low. The increasing positive influence of June temperatures on radial growth from the late 80 s of the last century and the increasing trend of the climatic signal for the density of late wood should be pointed out. The pine from Spasskaya Pad was characterized by negative correlations between the temperature in June and the parameters of the annual rings. 
The absence of a significant effect of the amount of June precipitation on the radial growth and the anatomical parameters of the larch from Evenkia was confirmed by the very low values of "sliding correlations". It is interesting to note the increase in the positive relationship between the efficiency of water supply and the amount of June rainfall for spruce from Evenkia, and the emergence of a significant correlation $(p<0.05)$ since 1985. For larch from Yakutia, such a relationship has been observed since 1977. For the parameters of the annual rings of pine from Spasskaya Pad, the amount of precipitation had a positive effect over the entire period during 1960-2011, although the signal was not always stable and rarely reached significant correlation coefficients.

\section{CONCLUSIONS}

The data obtained as a result of our study showed climate-related changes in the tree-ring growth and the xylem anatomical parameters of the four studied conifer species in the permafrost zone from 1960 to 2011. Regional and local growing conditions and features of the hydrothermal regime of permafrost soils modified the effect of climatic factors and had a different effect on the radial growth and anatomical structure of the xylem of the studied species. For example, for a relatively large amount of precipitation compared to Yakutia and the growth of larch and spruce in Evenkia on alluvial humus soils, an increase in summer temperatures can affect the degradation of permafrost, providing trees with an additional source of moisture, which, in turn, increases the growth and productivity of discussed species. For the territory of Central Yakutia, an increase in summer temperatures will be a source of progressively increasing drought stress, suppressing the basic physiological processes of growth, and, as a result, causing new structural and functional changes in xylem.

\section{FUNDING}

The study was supported by the Russian Science Foundation (grant no. 14-14-00219 P) and the grant of the President of Russian Federation, project no. MK-1589.2014.4.

\section{COMPLIANCE WITH ETHICAL STANDARDS}

Conflict of interests. The authors declare that they have no conflicts of interest.

Statement on the welfare of animals. This article does not contain any studies involving animals performed by any of the authors.

\section{REFERENCES}

Abaimov, A.P., Bondarev, A.I., Zyryanova, O.A., and Shitova, S.A., Lesa Krasnoyarskogo Zapolyar'ya (Forests of the Krasnoyarsk Arctic Region), Novosibirsk: Nauka, 1997.

Ben'kova, V.E. and Ben'kova, A.V., Specific structure of wood of northern populations of Siberian species of larch, Lesovedenie, 2006, no. 4, pp. 28-36.

Bréda, N., Huc, R., Granier, A., and Dreyer, E., Temperate forest trees and stands under severe drought: a review of ecophysiological responses, adaptation processes and long-term consequences, Ann. For. Sci., 2006, vol. 63, pp. 625-644.

Briffa, K.R., Osborn, T.J., Schweingruber, H.F., Harris, I.C., Jones, P.D., Shiyatov, S.G., and Vaganov, E.A., Low frequency temperature variations from a northern tree-ring density network, J. Geophys. Res.: Atmos., 2001, vol. 106, no. 3, pp. 2929-2941.

Bryukhanova, M.V., Kirdyanov, A.V., Sviderskaya, I.V., and Pochebyt, N.P., Impact of weather conditions on anatomical structure of annual rings of Dahurian larch on the north of Central Siberia, Lesovedenie, 2014, no. 4, pp. 36-40.

Bryukhanova, M.V., Fonti, P., Kirdyanov, A.V., Siegwolf, R.T.W., Saurer, M., Pochebyt, N.P., Churakova (Sidorova), O.V., and Prokushkin, A.S., The response of $\delta^{13} \mathrm{C}, \delta^{18} \mathrm{O}$ and cell anatomy of Larix gmelinii tree rings to differing soil active layer depths, Dendrochronologia, 2015, vol. 34, pp. 51-59.

Castagneri, D., Petit, G., and Carrer, M., Divergent climate response on hydraulic-related xylem anatomical traits of Picea abies along a 900-m altitudinal gradient, Tree Physiol., 2015, vol. 5, no. 12, pp. 1378-1387.

Davi, N., Jacoby, G., and Wiles, G., Boreal temperature variability inferred from maximum latewood density and tree-ring width data, Wrangell mountain region, Alaska, Quat. Res., 2003, vol. 60, no. 3, pp. 252-262.

Delisle, G., Near-surface permafrost degradation: how severe during the 21st century? Geophys. Res. Lett., 2007, vol. 34, art. ID L09503.

Denne, M.P., Definition of latewood according to Mork (1928), IAWA Bull., 1989, vol. 10, pp. 59-62.

Eilmann, B., Zweifel, R., Buchmann, H., Fonti, P., and Rigling, A., Drought-induced adaptation of the xylem in Scots pine and pubescent oak, Tree Physiol., 2009, vol. 29, no. 8, pp. 1011-1020.

Fonti, P. and Babushkina, E.A., Tracheid anatomical responses to climate in a forest-steppe in Southern Siberia, Dendrochronologia, 2016, vol. 39, pp. 32-41.

Gartner, B., Patterns of xylem variation within a tree and their hydraulic and mechanical consequences, in Plant Stems: Physiology and Functional Morphology, San Diego: Academic, 1995, pp. 125-149.

Hacura, J., Gryc, V., Vavrčík, H., Hozová, J., and Urban, J., The effect of drought on cell wall thickness and radial dimension of tracheids of Picea abies (L.) Karst., Wood Res., 2015, vol. 60, no. 2, pp. 175-188.

Holmes, R.L., Computer-assisted quality control in treering dating and measurement, Tree Ring Bull., 1983, vol. 43, pp. 69-78.

IPCC 2013, Climate Change 2013: The Physical Science Basis. Contribution of Working Group I to the Fifth Assessment Report of the Intergovernmental Panel on Climate Change, Stocker, T.F., Qin, D., Plattner, G.-K., Tignor, M., Allen, S.K., Boschung, J., Nauels, A., Xia, Y., Bex, V., 
and Midgley, P.M., Eds., Cambridge: Cambridge Univ. Press, 2013.

Iverson, L.R. and Prasad, A.M., Potential changes in tree species richness and forest community types following climate change, Ecosystems, 2001, vol. 4, no. 3, pp. 186-199.

Jagels, S.R. and Visscher, G.E., A synchronous increase in hydraulic conductive capacity and mechanical support in conifers with relatively uniform xylem structure, $A m$. J. Bot., 2006, vol. 93, no. 2, pp. 179-187.

Kujansuu, J., Yasue, K., Koike, T., Abaimov, A.P., Kajimoto, T., Takeda, T., Tokumoto, M., and Matsuura, Y., Responses of ring widths and maximum densities of Larix gmelinii to climate on contrasting north- and south-facing slopes in central Siberia, Ecol. Res., 2007, vol. 22, no. 4, pp. 582-592.

Kuz'min, S.R. and Togovtsev, R.V., Radial growth and a part of later wood in Scots pine in geographical cultures in Western and Central Siberia, Sib. Ekol. Zh., 2016, no. 6 , pp. $113-125$.

Lloyd, A.H. and Bunn, A.G., Responses of the circumpolar boreal forest to 20th century climate variability, Environ. Res. Lett., 2007, vol. 2, no. 4, p. 045013.

Martin-Benito, D., Beeckman, H., and Cañellas, I., Influence of drought on tree rings and tracheid features of Pinus nigra and Pinus sylvestris in a mesic Mediterranean forest, Eur. J. For. Res., 2013, vol. 132, no. 1, pp. 33-45.

Nikolaev, A.N., Fedorov, P.P., and Desyatkin, A.R., Effect of hydrothermal conditions of permafrost soil on radial growth of larch and pine in Central Yakutia, Contemp. Probl. Ecol., 2011, vol. 4, no. 2, pp. 140-149.

Ohse, B., Jansen, F., and Wilmking, M., Do limiting factors at Alaskan tree lines shift with climate regimes? Environ. Res. Lett., 2012, vol. 7, no. 1, p. 015505.

Panyushkina, I.P., Hughes, M.K., Vaganov, E.A., and Munro, M.A.R., Summer temperature in northeastern Siberia since 1642 reconstructed from tracheid dimensions and cell numbers of Larix cajanderi, Can. J. For. Res., 2003, vol. 33, no. 10, pp. 1905-1914.

Rinn, F., Tsap V. 3.6 Reference Manual: Computer Program for Tree-Ring Analysis and Presentation, Heidelberg: Frank Rinn Distribution, 1996.

Romanovsky, V.E., Kholodov, A.L., Marchenko, S.S., Oberman, N.G., Drozdov, D.S., Malkova, G.V., Moskalenko, N.G., Vasiliev, A.A., Sergeev, D.O., and Zheleznyak, M.N., Thermal state and fate of permafrost in Russia: first results of IPY (plenary paper), Proc. Ninth Int. Conf. on Permafrost, June 29-July 3, 2008, Kane, D.L. and Hinkel, E.M., Eds., Fairbanks: Inst. North. Eng., 2008, vol. 2, pp. 1511-1518.

Serreze, M.C., Walsh, J.E., Chappin, III, F.S., Osterkamp, T., Dyurgerov, M., Romanovsky, V., Oechel, W.C., Morison, J., Zhang, T., and Barry, R.G., Observational evidence of recent change in the northern high-latitude environment, Clim. Change, 2000, vol. 46, nos. 1-2, pp. 159-207.

Shashkin, A.V. and Vaganov, E.A., Simulation model of climatically determined variability of conifers' annual in- crement (on the example of common pine in the steppe zone), Russ. J. Ecol., 1993, vol. 24, no. 4, pp. 275-280.

Shishov, V.V., Tychkov, I.I., Popkova, M.I., Ilyin, V.A., Bryukhanova, M.V., and Kirdyanov, A.V., VS-oscilloscope: a new tool to parameterize tree radial growth based on climate conditions, Dendrochronologia, 2016, vol. 39, pp. 42-50.

Shur, Y.L. and Jorgenson, M.T., Patterns of permafrost formation and degradation in relation to climate and ecosystems, Permafrost Periglacial Process., 2007, vol. 18, no. 1 , pp. 7-19.

Siman'ko, V.V., Specific radial growth and structure of annual rings of Dahurian larch in Taimyr Peninsula and Kotuiskaya Upland, Extended Abstract of Cand. Sci. (Biol.) Dissertation, Krasnoyarsk: Sukachev Inst. Forest, Siberian Branch, Russ. Acad. Sci., 2014.

Siman'ko, V.V., Ben'kova, V.E., and Shashkin, A.V., Application of the "moving response functions" method to identify the influence of climatic factors on the radial growth of trees, Vestn. Krasn. Gos. Agrar. Univ., 2013, no. 7, pp. 188-194.

Sperry, J.S., Hacke, U.G., and Pittermann, J., Size and function in conifer tracheids and angiosperm vessels, Am. J. Bot., 2006, vol. 93, pp. 1490-1500.

Sviderskaya, I.V., Sukhovol'skii, V.G., Radosteva, E.Yu., and Kirdyanov, A.V., Model evaluation of optimal ratio between the width of cell wall and lumen size in tracheids of coniferous, Zh. Sib. Fed. Univ., Biol., 2011, vol. 2, no. 4, pp. 183-196.

Tabakova, M.A., Kirdyanov, A.V., Bryukhanova, M.V., and Prokushkin, A.S., Dependence of ingrowth of Dahurian larch on local growing conditions in the north of Central Siberia, Zh. Sib. Fed. Univ., Biol., 2011, vol. 4, no. 4, pp. 314-324.

Tchebakova, N.M., Rehfeldt, G., and Parfenova, E.I., From vegetation zones to climatypes: effects of climate warming on Siberian ecosystems, in Permafrost Ecosystems: Siberian Larch Forests, Ecological Studies vol. 209, Osawa, A., Zyryanova, O.A., Matsuura, Y., Kajimoto, T., and Wein, R.W., Eds., Berlin: SpringerVerlag, 2010, pp. 427-446.

Vaganov, E.A., Mechanisms and simulation mode of development of the structure of annual rings in coniferous, Lesovedenie, 1996, no. 1, pp. 3-15.

Vaganov, E.A., Kirdyanov, A.V., and Silkin, P.P., Role of early-summer air temperature and snow cover melting period for growth of trees in subarctic zone of Siberia, Lesovedenie, 1999, no. 6, pp. 3-14.

Vaganov, E.A., Hughes, M.K., and Shashkin, A.V., Growth Dynamics of Conifer Tree Rings: Images of Past and Future Environments, Berlin: Springer-Verlag, 2006.

Vaganov, E.A., Skomarkova, M.V., Schulze, E.-D., and Linke, P., Effect of climatic factors on density of wood of annual rings of spruce and pine in the mountains of Northern Italy, Lesovedenie, 2007, no. 2, pp. 37-44.

Ziaco, E., Biondi, F., and Heinrich, I., Wood cellular dendroclimatology: testing new proxies in Great Basin Bistlecone pine, Front. Plant Sci., 2016, vol. 7, p. 1602.

Translated by V. Mittova 